\title{
Polymorphic site index curves for black spruce and trembling aspen in northwest Ontario
}

\author{
by Willard H. Carmean ${ }^{1}$, G. Hazenberg ${ }^{1}$ and K.C. Deschamps ${ }^{2}$
}

\begin{abstract}
Site index curves were developed using stem-analysis data from dominant and codominant trees in 230 black spruce and 194 trembling aspen plots located in mature, well-stocked, even-aged stands. Black spruce plots were in five separate and independent data sets located on mineral and organic soils; trembling aspen plots were in three separate and independent data sets located on mineral soils. Computations showed that the Newnham nonlinear regression model was slightly more precise than other models commonly used for developing site index curves. This model accurately expresses polymorphic height growth for a wide range of site index and age and constrains predicted height to agree with specified 50year tree height (site index). Computations showed that height-growth curves were similar for each of the five black spruce data sets; likewise, curves for each of the three trembling aspen data sets were similar. Therefore, the five black spruce and the three trembling aspen data sets were combined for computing a single set of black spruce and a single set of trembling aspen site index curves for Northwest Ontario. Comparisons between our Northwest Ontario site index curves and other black spruce and trembling aspen curves showed large differences in height-growth patterns for older ages. Reasons for these differences are uncertain but in many instances these could be artifacts related to study methods involving various amounts and kind of data and variations in analytical techniques. In some cases differences in climate, soil and topography may also be related to variations in these site curves.
\end{abstract}

Key words: site quality evaluation, polymorphic height growth, site index curve comparisons

\section{RÉSUMÉ}

Des courbes d'indices de station ont été élaborées par l'analyse des données des tiges dominantes et co-dominantes de 230 parcelles d'épinette noire et de 194 parcelles de peuplier faux-tremble situées dans des peuplements mûrs, denses et équiennes. Les parcelles d'épinette noire comprenaient cinq ensembles de données distincts et indépendants situés sur des sols minéraux. Les calculs ont montré que le modèle de régression non-linéaire de Newnham était un peu plus précis que les autres modèles couramment utilisés pour élaborer des courbes d'indices de station. Ce modèle exprime avec précision la croissance en hauteur polymorphique pour une grande partie des indices de station et d'âge ainsi que les hauteurs prédites par contraintes pour être en accord avec la hauteur des arbres à 50 ans (indice de station). Les calculs ont montré que les courbes de croissance en hauteur de chacun des cinq ensembles de données d'épinette noire et, de façon similaire, les courbes de chacun des trois ensembles de données de peuplier faux-tremble étaient semblables. En conséquence, les cinq ensembles de données d'épinette noire et les trois ensembles de données de peuplier faux-tremble ont été combinés pour générer un seul ensemble de courbes d'indices de station d'épinette noire et un seul ensemble pour le peuplier faux-tremble du nord-ouest de l'Ontario. Les comparaisons entre nos courbes d'indices de station du nord-ouest de l'Ontario et les autres courbes pour l'épinette noire et le peuplier faux-tremble ont souligné de fortes différences dans les patrons de croissance en hauteur à des âges avancés. Les raisons de ces différences sont incertaines mais dans plusieurs cas, elles pourraient être des artefacts reliés aux méthodes d'étude comprenant diverses quantités et genres de données et des variations dans les techniques analytiques. Dans certains cas, les différences climatiques, pédologiques et topographiques pourraient être également reliées aux variations de ces courbes de station.

Mots clés : évaluation de la qualité de la station, croissance en hauteur polymorphique, comparaisons de courbes d'indices de station

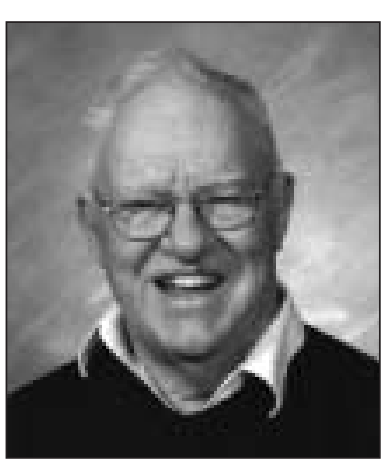

Willard H. Carmean

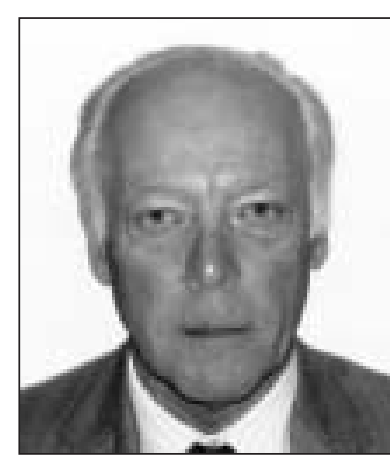

G. Hazenberg

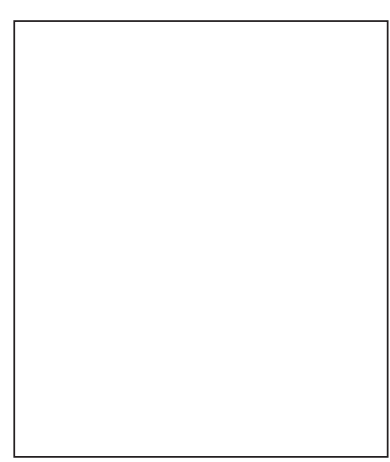

K.C. Deschamps

${ }^{1}$ Faculty of Forestry and the Forest Environment, Lakehead University, Thunder Bay, Ontario P7B 5E1. E-mail: address: sandy.dunning@ lakeheadu.ca

${ }^{2}$ Canadian Forest Products, Prince George, British Columbia V2K 3X6. 


\section{Introduction}

Black spruce (Picea mariana (Mill.) BSP) is among the most widespread and economically important trees in North America (Viereck and Johnson 1990). Almost 31\% of the total forest area in the Northwest Region ${ }^{3}$ of Ontario is spruce (OMNR 2002); the large volume and area of black spruce in this region is related to wildfire that has produced extensive areas of frequently pure, well-stocked, even-aged stands. Black spruce has semi-serotinous cones that disperse large quantities of seed following fire and black spruce on organic soils frequently regenerates from layering (Viereck and Johnson 1990).

Trembling aspen (Populus tremuloides Michx.) also is among the most widespread and economically important trees in North America (Perala 1990). The area of aspen (21\%) in Northwest Ontario is only exceeded by the area of black spruce (OMNR 2002). The large area and volume for trembling aspen in Northwest Ontario is also related to wildfire and to past harvesting that has produced well-stocked even-aged stands regenerated from root suckers. Surveys show that after harvesting regeneration is often pure aspen or mixedwood conifer and aspen stands (Hearnden et al. 1992). Greatly increased aspen utilization has developed for a wide variety of forest products and several symposia and literature reviews recognize the need for better utilization and management of an increasingly valuable aspen forest resource that in the past was often viewed as a forest weed (Davidson et al. 1988; Adams 1990; Navratil and Chapman 1991; Peterson and Peterson 1992, 1995; Morley and Balatinecz 1993; Navratil et al. 1994; David et al. 2001; Shepperd et al. 2001).

Intensive management for black spruce and trembling aspen requires the ability to estimate site quality and the potential growth and yield that can be attained for fullystocked stands having different levels of site quality. A variety of quantitative tools can be used for estimating site quality, including site index curves, growth intercepts, species site index comparisons and soil-site evaluation (Carmean 1975). Armed with site quality and yield information intensive management can be concentrated on the most productive forest sites that are capable of quickly producing large yields of valued forest products (Carmean 1996).

Good sites for black spruce usually are upland mineral soils such as deep, well-drained, lacustrine silts and clays, deep silty-textured glaciofluvial soils as well as morainal soils with little gravel; poor sites for black spruce are upland soils such as drier outwashed glacial sands, shallow to bedrock soils and gravelly glacial moraines. Black spruce is also commonly found on deep, poorly decomposed organic soils where site quality usually is poor; however, better sites may occur where organic soils are shallow and well decomposed, such as are often found on edges of peat bogs where water flow from adjacent uplands provides more nutrients and better aeration (Carmean 1996).

Knowing site quality is particularly important for trembling aspen because on good sites aspen is a fast-growing and commercially desirable tree. Good sites for trembling aspen in Northwest Ontario are usually well-drained lacustrine silts

\footnotetext{
${ }^{3}$ The North Central and Northwestern Regions of the Ontario Ministry of Natural Resources were combined into a single Northwest Region in June, 1993.
}

and clays and deeper medium-textured well-drained morainal and glaciofluvial soils (Carmean and Li 1998). On these good sites aspen regenerates well, grows rapidly, produces large yields and maintains good growth for at least 70 or 80 years. In contrast, poor sites for trembling aspen are shallow to bedrock soils, gravelly morainal soils, coarse-textured sands and poorly-drained mineral and organic soils. On these poor sites aspen growth is slow, yields are small, defects and disease are common and "stand breakup" occurs at relatively young ages (Fralish 1972, Shields and Bockheim 1981, Perala 1991, Carmean 1996).

Relatively few site index curves have been published for black spruce and trembling aspen in Canada and in the northern United States (Table 1) despite the large area and great economic importance of these species (Carmean et al. 1989). Most earlier site index curves for these species were based on total-age and total-height data collected from regional growth and yield studies; these older anamorphic curves are not capable of expressing polymorphic patterns of tree height growth. More recent polymorphic site index curves are based on stem-analysis data, on breast-height age and on nonlinear regression models that are capable of expressing polymorphic tree height growth.

Our major objective was to develop accurate site index curves for black spruce and trembling aspen in Northwest Ontario. For both species we had a large number of plots with much stem-analysis data representing a wide range of site index and age; therefore, we were able to make many analyses not usually used for developing site index curves: (a) determining what was the most precise height-growth model to use; (b) determining what maximum age of data to include when formulating site index curves; (c) determining if polymorphic height-growth patterns are associated with different levels of site index; and (d) determining if height-growth patterns differed between mineral and organic soils in the North Central and Northwestern Regions of Northwest Ontario. A secondary objective was to compare our site index curves for Northwest Ontario to site index curves for black spruce and trembling aspen in other areas of Canada and the United States.

\section{The Data}

Stem-analysis data were collected from 230 black spruce and 194 trembling aspen plots 0.08 ha in size located in natural, even-aged, fully-stocked undisturbed stands that were 50 years breast-height age and older (Table 2). The black spruce plots were in five separate and independent data sets and the trembling aspen plots were in three separate and independent data sets. Plots were established where microtopography was even and unbroken and where soil and topographic conditions within plots appeared similar. An effort was made to establish plots representing a wide range of site quality and age for soils developed on the major glacial landforms commonly found in Northwest Ontario.

One to five well-formed, uninjured dominant and codominant trees were selected for stem analysis on each plot. Obtaining measurable trembling aspen trees on poorer sites was often difficult because trees frequently had heart rot making ring counts difficult, or trees had erratic height-growth patterns probably due to top breakage or top dieback. As a result, some aspen plots on poorer sites were represented by only a single usable tree. 


\begin{tabular}{|c|c|c|c|c|c|c|c|c|c|c|}
\hline & $\begin{array}{l}\text { No. of } \\
\text { plots }\end{array}$ & $\begin{array}{l}\text { No. of } \\
\text { trees }\end{array}$ & $\begin{array}{c}\text { Type } \\
\text { of tree }^{\mathrm{a}}\end{array}$ & $\begin{array}{c}\text { Type } \\
\text { of data }^{b}\end{array}$ & $\begin{array}{l}\text { Site index } \\
\text { definition }^{c}\end{array}$ & $\begin{array}{l}\text { Range of } \\
\text { site index } \\
\text { (m) }\end{array}$ & $\begin{array}{l}\text { Range } \\
\text { of age } \\
\text { (years) }\end{array}$ & $\begin{array}{l}\text { Type of } \\
\text { analysis }^{d}\end{array}$ & $\begin{array}{l}\text { Type of } \\
\text { Curve }^{e}\end{array}$ & Citation \\
\hline \multicolumn{11}{|l|}{ Black spruce } \\
\hline NE Minnesota & $\mathrm{nk}^{\mathrm{f}}$ & nk & $\mathrm{D}, \mathrm{CD}$ & HA & $\mathrm{H} / \mathrm{TA}$ & $\mathrm{nk}$ & $\mathrm{nk}$ & LR & A & Gevorkiantz (1957) \\
\hline N Ontario & nk & $\mathrm{nk}$ & $\mathrm{D}, \mathrm{CD}$ & SA & H/TA & nk & $\mathrm{nk}$ & G & A & Plonski (1974) \\
\hline E Canada & 124 & 1169 & $\mathrm{D}, \mathrm{CD} ; \mathrm{I}, \mathrm{S}$ & SA & $\mathrm{H} / \mathrm{BHA}$ & $\mathrm{nk}$ & $50-240$ & LR & $\mathrm{A}$ & Heger and Lowry (1971) \\
\hline ON Clay Belt & $\mathrm{nk}$ & 60 & $\mathrm{D}, \mathrm{CD}$ & SA & $\mathrm{H} / \mathrm{TA}$ & $1-12$ & $43-287$ & NLR & $\mathrm{P}$ & Payandeh (1978) \\
\hline Yukon & 108 & nk & $\mathrm{D}, \mathrm{CD}$ & SA & $\mathrm{H} / \mathrm{BHA}$ & $\mathrm{nk}$ & $\mathrm{nk}$ & LR & A & Quenet and Manning (1990) \\
\hline N. Brunswick & $\mathrm{nk}$ & 354 & $\mathrm{D}, \mathrm{CD}$ & SA & $\mathrm{H} / \mathrm{BHA}$ & $4-17$ & $50-203$ & NLR & $\mathrm{P}$ & Ker and Bowling (1991) \\
\hline Newfoundland & 129 & $\mathrm{nk}$ & $\mathrm{D}$ & PP & $\mathrm{H} / \mathrm{BHA}$ & $\mathrm{nk}$ & $1-140$ & ILR & $\mathrm{P}$ & Newton (1992) \\
\hline Alberta & $\mathrm{nk}$ & 282 & $\mathrm{D}, \mathrm{CD}$ & SA & $\mathrm{H} / \mathrm{BHA}$ & $4-16$ & $50-190$ & NLR & $\mathrm{P}$ & Cieszewski and Bella (1991) \\
\hline Saskatchewan & nk & 55 & $\mathrm{D}, \mathrm{CD}$ & SA & $\mathrm{H} / \mathrm{BHA}$ & $6-18$ & $50-140$ & NLR & $\mathrm{P}$ & Cieszewski et al. (1994) \\
\hline N Central Man. & nk & 95 & $\mathrm{D}, \mathrm{CD}$ & SA & $\mathrm{H} / \mathrm{BHA}$ & $4-18$ & $69-203$ & NLR & $\mathrm{P}$ & Pollock (1994), Cole (1996) \\
\hline ON Clay Belt & 44 & nk & $\mathrm{TH}$ & $\mathrm{PP}$ & $\mathrm{H} / \mathrm{TA}$ & nk & 9-91 & NLR & $\mathrm{P}$ & Larocque et al. (1996) \\
\hline N British Columbia & 91 & $\mathrm{nk}$ & $\mathrm{D}, \mathrm{CD}$ & SA & H/BHA & $5-17$ & $51-174$ & NLR & $\mathrm{P}$ & Nigh et al. (2002) \\
\hline \multicolumn{11}{|l|}{ Trembling aspen } \\
\hline Lake States & nk & nk & $\mathrm{D}, \mathrm{CD}$ & $\mathrm{HA}$ & $\mathrm{H} / \mathrm{TA}$ & nk & nk & LR & A & Gevorkiantz (1956) \\
\hline N Ontario & nk & nk & $\mathrm{D}, \mathrm{CD}$ & SA & $\mathrm{H} / \mathrm{TA}$ & nk & nk & G & A & Plonski (1974) \\
\hline Alaska & 14 & 43 & $\mathrm{D}, \mathrm{CD}$ & SA & $\mathrm{H} / \mathrm{TA}$ & $11-23$ & $50-100$ & NLR & $\mathrm{P}$ & Gregory and Haack (1965) \\
\hline Newfoundland & 94 & 376 & $\mathrm{D}$ & HA & $\mathrm{H} / \mathrm{TA}$ & $\mathrm{nk}$ & $19-116$ & G & A & Page (1972) \\
\hline Central Rocky Mts & 245 & $\mathrm{nk}$ & $\mathrm{D}$ & HBHA & H/BHA80 & $\mathrm{nk}$ & $10-192$ & NLR & $\mathrm{P}$ & Edminster et al. (1985) \\
\hline Alberta & $\mathrm{nk}$ & 202 & $\mathrm{D}, \mathrm{CD}$ & SA & H/BHA & $8-25$ & $50-140$ & NLR & $\mathrm{P}$ & Cieszewski and Bella (1991) \\
\hline Saskatchewan & nk & 64 & $\mathrm{D}, \mathrm{CD}$ & SA & $\mathrm{H} / \mathrm{BHA}$ & $8-24$ & $50-110$ & NLR & $\mathrm{P}$ & Cieszewski et al. (1994) \\
\hline N British Columbia & 33 & 99 & $\mathrm{D}$ & SA & $\mathrm{H} / \mathrm{BHA}$ & $5-25$ & $51-70$ & NLR & $\mathrm{P}$ & Chen et al. (1998) \\
\hline N Mich and Wisc ${ }^{g}$ & 13 & 42 & $\mathrm{D}, \mathrm{CD}$ & SA & $\mathrm{H} / \mathrm{TA}$ & $17-26$ & $50-70$ & NLR & $\mathrm{P}$ & Carmean (1978) \\
\hline
\end{tabular}

Type of trees: $\mathrm{D}$ = Dominant; $\mathrm{CD}=$ Codominant; I = Intermediate; $\mathrm{S}=$ Suppressed; $\mathrm{TH}$ = Top Height.

bType of data: $\mathrm{HA}=$ Height and total-age values; $\mathrm{SA}=$ Stem analysis; $\mathrm{PP}=$ Permanent plot remeasurements; HBHA = Breast-height age.

cSite index definitions: $\mathrm{H} / \mathrm{TA}=$ Average height of $\mathrm{D}$ and $\mathrm{CD}$ trees at 50 years total-age; H/BHA = Height of $\mathrm{D}$ and $\mathrm{CD}$ trees at 50 years breast-height age; $\mathrm{H} / \mathrm{BHA} 80=\mathrm{Height}$ of $\mathrm{D}$ and $\mathrm{CD}$ trees at 80 years breast-height age.

dType of analysis: LR = Linear regression; G = Graphical; NLR = Nonlinear regression; ILR = Inverse log regression.

'Type of curves: $\mathrm{A}=$ Anamorphic; $\mathrm{P}$ = Polymorphic.

${ }^{\mathrm{f}} \mathrm{nk}=$ not known.

gThe Carmean (1978) curves used combined data from trembling and largetooth aspen (Populus grandidenta Michx.).

Trees were sectioned at ground level, at $0.75,1.3$ and $2.0 \mathrm{~m}$, at $1.0-\mathrm{m}$ intervals up to $13.0 \mathrm{~m}$ and, thereafter, at $0.5-\mathrm{m}$ intervals up to the terminal leader of the tree. Age at each sectioning height was determined in the laboratory by cutting a clean surface on the sectioned disk and then counting annual rings using magnification and illumination. This tedious and timeconsuming task was facilitated using a computerized Tree Ring Increment Measuring (TRIM) system (MacIver et al. 1985) that magnifies annual rings, provides a computer screen for viewing and automatically records and enters data into a computer file.

A height-age curve for each site tree on each plot was graphed and inspected for abnormal height growth that might have been caused by early suppression, by top damage or by breakage. We found that the individual tree height-age curves on each plot usually were similar and had similar heights at 50 years; only a few trees were discarded when obvious abnormal height-growth patterns were observed.

Corrections for each individual tree height-age curve were made for a small bias that occurs where height at sectioning points underestimates actual height attained for a particular year (Carmean 1972, Dyer and Bailey 1987, Carmean and Lenthall 1989). This bias occurs because sectioning points will almost always be at some intermediate point along the annual leader rather than at the terminal bud. The small bias can be removed based on the assumption that sectioning points will, on the average, fall in the middle of the annual leaders. We removed this bias from each site tree by increasing height at each section point by one-half the estimated length of the annual leader; a program for removing this bias was added to the TRIM tree ring counting system. The corrected individual tree height-age curves on each plot then were combined into a corrected average height-age curve for each plot. Occasional sectioned trees were a few years older than the other sectioned trees on a plot; however, the average curve for each plot was extended only to ages where height observations were available from all sectioned trees on the plot.

Site index was defined as the average height $(\mathrm{m})$ of dominant and codominant trees 50 years after they reached breast height $(1.3 \mathrm{~m})$. We estimated site index for each plot using the corrected average height-age curve for the plot to observe average tree height at the 50 -year breast-height age. Breastheight age was used for our curves because our individual tree curves usually showed slow and erratic height growth before reaching breast height.

Site indices for the 230 black spruce plots ranged from 3.5 to $19.7 \mathrm{~m}$ and ages ranged from 50 to 180 years breast-height age (Table 2); we found that trees on 87 of the 230 plots exceeded 100 years breast-height age (Table 3 ). A strong and consistent trend for older black spruce plots to be on poor 
Table 2. Site index curves for black spruce and trembling aspen in Northwest Ontario were developed using stem-analysis data from dominant and codominant trees growing in natural, fully-stocked, even-aged stands. The 230 black spruce plots were in five separate and independent data sets and the 194 trembling aspen plots were in three separate and independent data sets.

Black spruce

\begin{tabular}{|c|c|c|c|}
\hline Data set and region ${ }^{b}$ & $\begin{array}{l}\text { Total } \\
\text { plots }\end{array}$ & $\begin{array}{c}\text { BH-age } \\
\text { range } \\
\text { (years) }\end{array}$ & $\begin{array}{l}\text { Site index } \\
\text { range } \\
(\mathrm{m})\end{array}$ \\
\hline Mineral soils & 86 & $50-147$ & $3.9-19.7$ \\
\hline NW Mineral soils & 58 & $50-180$ & $5.6-18.8$ \\
\hline Organic soils & 44 & $50-145$ & $3.5-16.6$ \\
\hline Organic soils & 23 & $56-166$ & $4.4-15.9$ \\
\hline $\begin{array}{cc}\mathrm{NC}^{\mathrm{c}} \quad \begin{array}{c}\text { Mineral and } \\
\text { organic soils }\end{array}\end{array}$ & 19 & $50-143$ & $8.4-19.7$ \\
\hline Northwest Ontario & 230 & $50-180$ & $3.5-19.7$ \\
\hline
\end{tabular}

Trembling aspen

\begin{tabular}{lccc}
\hline & $\begin{array}{c}\text { Total } \\
\text { plots }\end{array}$ & $\begin{array}{c}\text { BH-age } \\
\text { range } \\
\text { (years) }\end{array}$ & $\begin{array}{c}\text { Site index } \\
\text { range } \\
(\mathbf{m})\end{array}$ \\
\hline $\begin{array}{l}\text { NC (Deschamps 1991) } \\
\text { NW (Li 1991) and FEC }\end{array}$ & 89 & $50-110$ & $15.7-27.0$ \\
$\quad($ Sims et. al. 1989) & 59 & $50-135$ & $9.3-24.7$ \\
$\begin{array}{l}\text { NC and NW FEC } \\
\quad(\text { Sims et al. 1989) }\end{array}$ & 46 & $50-105$ & $13.7-25.8$ \\
$\begin{array}{l}\text { Northwest Ontario } \\
\text { (10) }\end{array}$ & 194 & $50-135$ & $9.3-27.0$ \\
\hline
\end{tabular}

asite index is average height $(\mathrm{m})$ of dominant and codominant trees at 50 years breast-height $(1.3 \mathrm{~m})$ age.

${ }^{\mathrm{b}} \mathrm{NW}=$ Northwestern Region, NC $=$ North Central Region.

${ }^{\mathrm{c}}$ Kimberly-Clark permanent sample plots located mostly on mineral soils but some organic soils were included.

${ }^{\mathrm{d}}$ FEC plots are Forest Ecological Classification system plots.

sites was found for each of our five independent data sets for both mineral and organic soils in the North Central and Northwestern Ontario Regions of Northwest Ontario. Lack of older black spruce plots on good sites may be due to windthrow of older shallow-rooted black spruce trees after they reach a critical height of 20 to $21 \mathrm{~m}$ (Smith et al. 1987).

Site indices for the 194 trembling aspen plots ranged from 9.3 to $27.0 \mathrm{~m}$ and ages ranged from 50 to 135 years breastheight age (Table 2 ). Thirty plots represented very good site indices (SI $>22.0 \mathrm{~m}$ ), 144 plots represented good site indices (SI 16.0 to $21.9 \mathrm{~m}$ ), 18 plots represented medium site indices (SI 12.0 to $15.9 \mathrm{~m}$ ) and only two plots were found on poor sites ( $\mathrm{SI}<12.0 \mathrm{~m}$ ) (Table 3 ). Most of the poor and medium site plots were in the 59-plot data set for the Northwestern Region provided by Li (1991) and the FEC (Forest Ecological Classification system) (Sims et al. 1989) where special efforts were made to locate usable plots on poorer sites.

\section{Analysis \\ Height-growth models}

Our preliminary analysis involved testing several heightgrowth models commonly used for formulating polymorphic site index curves. For model testing we used the entire 230plot black spruce data set and the entire 194-plot aspen data set, but we only used data from plots that were 100 years and less breast-height age. Models tested included the Ek (1971) nonlinear regression model and the Monserud (1984) logistic model. These two models produce polymorphic heightgrowth curves that may not pass exactly through tree height (site index) specified at index age. Accordingly we also tested two adaptations of the Ek model (Burkhart and Tennent 1977, Newnham 1988) and two adaptations of the Monserud model (Dempster and Associates 1983, Ker and Bowling 1991) that constrain height-growth curves to pass exactly through tree height specified at index age.

\section{Restricting maximum age of computation data}

For both species we had a large number of plots representing a wide range of site index for younger ages (Tables 2 and 3 ). However, for older ages both species had an abnormal distribution of plots in relation to site index. For black spruce most of the plots older than 100 years breast-height age were on poor (SI $<9.0 \mathrm{~m}$ ) and medium (SI 9.0 to $14.9 \mathrm{~m}$ ) sites (Table 3). Lack of black spruce plots older than 100 years on good sites $($ SI $>15.0 \mathrm{~m}$ ) might distort our formulations if data older than 100 years were used that were mostly from poorer sites. Should we use all of the older black spruce data from the plots on poorer sites, or should we only use data that were 100 years and less breast-height age for our computations?

For trembling aspen we had no difficulty locating older plots on good sites; locating older plots on poor sites was the problem. Most of the trembling aspen data for older ages were from plots on good and very good sites $(\mathrm{SI}>16.0 \mathrm{~m}$ ) and this lack of plots for older ages on poorer sites (SI $<12.0$ $\mathrm{m})$ might distort results of our computations.

For both species we addressed the site index distribution question by comparing height-growth curves computed using the following maximum age of data restrictions: (a) only use data that were 80 years and younger; (b) only use data that were 100 years and younger; and (c) use all older data from plots that were older than 100 years breast-height age. Separate Newnham (1988) nonlinear regression equations were computed using the above three maximum age of data restrictions. We then compared the precision of the height-growth curves generated by these three separate maximum age-restricted equations.

\section{Polymorphic height-growth patterns}

Different-shaped height-growth curves are often associated with level of site index (Carmean 1975, 1996; Carmean et al. 2001). For both species we wanted to know if polymorphism expressed by a single Newnham (1988) equation was similar to polymorphism expressed by separate equations using data restricted only to plots for poor, medium and good levels of site index.

Accordingly, for black spruce the entire 230-plot data set was stratified into the 48 plots representing poor sites (SI $<9.0 \mathrm{~m}$ ), the 133 plots representing medium sites (SI 9.0 to SI $14.9 \mathrm{~m}$ ) and the 49 plots representing good sites (SI > $15.0 \mathrm{~m}$ ). For trembling aspen the entire 194-plot data set was stratified into the 20 plots representing medium sites $(\mathrm{SI}<16.0 \mathrm{~m}$ ), the 144 plots representing good sites (SI 16.0 to SI $21.9 \mathrm{~m}$ ), and the 30 plots representing very good sites (SI > $22.0 \mathrm{~m}$ ). For both species separate Newnham (1988) equa- 
Table 3. Distribution of plots by age and site indexa classes for the 230 black spruce plots and the 194 trembling aspen plots

Black spruce

\begin{tabular}{|c|c|c|c|c|c|c|c|c|c|}
\hline \multirow{2}{*}{$\begin{array}{r}\text { BH-age } \\
\text { class (yrs) }\end{array}$} & \multicolumn{9}{|c|}{ Site index class ${ }^{\mathrm{a}}(\mathrm{m})$} \\
\hline & $<7.0$ & $7.0-8.9$ & $9.0-10.9$ & $11.0-12.9$ & $13.0-14.9$ & $15.0-16.9$ & $17.0-18.9$ & $>18.9$ & Totals \\
\hline $50-59$ & - & 3 & - & 3 & 5 & 9 & 6 & 2 & 28 \\
\hline $60-69$ & 1 & 2 & 1 & 1 & 6 & 6 & 7 & - & 24 \\
\hline $70-79$ & 1 & 1 & 2 & 8 & 4 & 6 & 1 & - & 23 \\
\hline $80-89$ & 1 & 1 & 5 & 13 & 12 & 6 & - & - & 38 \\
\hline 90-99 & 1 & 3 & 6 & 10 & 8 & 2 & - & - & 30 \\
\hline $100-109$ & 3 & 5 & 7 & 12 & 5 & 2 & - & - & 34 \\
\hline $110-119$ & 2 & 5 & 4 & 4 & 1 & - & - & - & 16 \\
\hline $120-129$ & - & 3 & 5 & 3 & 2 & 2 & - & - & 15 \\
\hline $130-139$ & 4 & 3 & 1 & 2 & 1 & - & - & - & 11 \\
\hline $140-149$ & 2 & 2 & - & - & 1 & - & - & - & 5 \\
\hline $150-159$ & 1 & - & - & - & - & - & - & - & 1 \\
\hline $160-169$ & 2 & 2 & - & - & - & - & - & - & 4 \\
\hline $170-179$ & - & - & - & - & - & - & - & - & - \\
\hline $180-189$ & - & - & - & 1 & - & - & - & - & 1 \\
\hline Totals & 18 & 30 & 31 & 57 & 45 & 33 & 14 & 2 & 230 \\
\hline
\end{tabular}

Trembling aspen

\begin{tabular}{|c|c|c|c|c|c|c|c|c|c|}
\hline \multirow{2}{*}{$\begin{array}{r}\text { BH-age } \\
\text { class (yrs) }\end{array}$} & \multicolumn{9}{|c|}{ Site index class ${ }^{\mathrm{a}}(\mathrm{m})$} \\
\hline & $<12.0$ & $12.0-13.9$ & $14.0-15.9$ & $16.0-17.9$ & $18.0-19.9$ & $20.0-21.9$ & $22.0-23.9$ & $>23.9$ & Totals \\
\hline $50-59$ & 2 & 3 & 5 & 10 & 21 & 16 & 14 & 4 & 75 \\
\hline $60-69$ & - & 1 & 4 & 10 & 22 & 17 & 5 & 2 & 61 \\
\hline $70-79$ & - & - & 1 & 4 & 9 & 9 & 2 & 1 & 26 \\
\hline $80-89$ & - & - & - & - & 4 & 4 & 2 & - & 10 \\
\hline $90-99$ & - & 1 & 2 & - & 3 & 6 & - & - & 12 \\
\hline $100-109$ & - & - & - & 3 & 3 & 2 & - & - & 8 \\
\hline $110-119$ & - & - & - & - & - & 1 & - & - & 1 \\
\hline $120-129$ & - & - & - & - & - & - & - & - & - \\
\hline $130-139$ & - & - & 1 & - & - & - & - & - & 1 \\
\hline Totals & 2 & 5 & 13 & 27 & 62 & 55 & 23 & 7 & 194 \\
\hline
\end{tabular}

aSite index is average height $(\mathrm{m})$ of dominant and codominant trees at 50 years breast-height $(1.3 \mathrm{~m})$ age.

tions were fitted to data for each of these three site classes using data 100 years and less breast-height age. We then compared height-growth patterns using these three separate and independent site-class equations with height-growth patterns using a single Newnham equation that included data 100 years and less breast-height age.

\section{Comparisons with other site index curves}

We compared our black spruce and trembling aspen site index curves to other black spruce and trembling aspen curves commonly used in Ontario as well as in Canada and the United States (Table 1). These comparisons between our curves and other black spruce curves were made using site index levels representing poor, medium and good levels of site index; for trembling aspen comparisons were made using medium, good and very good levels of site index.

Most of the other site index curves for black spruce and trembling aspen (Table 1) are based on breast-height age and they usually have formulations that can be used for generating height predictions for comparisons with our Northwest Ontario site index curves. However, four black spruce curves
(Gevorkiantz 1957, Plonski 1974, Payandeh 1978, Larocque et al. 1996) are based on total-age and the Gevorkiantz and Plonski curves have no values for ages less than 20 years totalage. For trembling aspen four curves (Gevorkiantz 1956, Gregory and Haack 1965, Plonski 1974, Carmean 1978) are based on total-age and three of these curves (Gevorkiantz 1956, Gregory and Haack 1965, Plonski 1974) have no values for ages less than 20 years total-age.

For comparisons with our breast-height age curves these eight total-age curves had to be adjusted to breast-height age and formulations had to be developed for generating height values that could be compared to our Northwest Ontario curves. For black spruce adjustments of the four total-age curves to breast-height age were accomplished by first projecting them back to their origin of 0 height at 0 years totalage. For the Gevorkiantz (1957) black spruce curves this was accomplished using a formulation by Lundgren and Dolid (1970) and for the Plonski (1974) curves we used a formulation by Payandeh (1974); the total-age black spruce curves for Ontario peatlands (Payandeh 1978) and the Larocque et al. (1996) Ontario Clay Belt curves included formulations for 
generating total-age curves. These four generated total-age curves then were used to estimate the number of years for black spruce to reach breast height for poor $(\mathrm{SI}=7 \mathrm{~m})$, medi$\mathrm{um}(\mathrm{SI}=12 \mathrm{~m})$ and good $(\mathrm{SI}=17 \mathrm{~m})$ levels of site index.

Black spruce breast-height age curves for site indices 7, 12 and $17 \mathrm{~m}$ were attained by eliminating all data younger than the estimated years required for black spruce to reach breast height. Curves then were started at breast height (0 years at $\mathrm{BH}$ ) and site index was defined as height at 50 years breastheight age. Some minor proportional adjustments were needed so that these curves passed exactly through the specified 50 -year height for each of the three levels of site index.

Adjustments for the four trembling aspen total-age curves were similar to adjustments described for black spruce. Formulations were available for the Plonski curves (Payandeh 1974), the Gevorkiantz curves (Lundgren and Dolid 1970) and the Carmean curves (Carmean et al. 1989); we formulated the Gregory and Haack (1965) total-age curves using values listed in their publication. Formulations for these four curves were used to generate total-age curves for site index classes 15, 19 and $23 \mathrm{~m}$. These generated total-age curves were then used to estimate the number of years for trembling aspen to reach breast height for site index classes 15, 19 and $23 \mathrm{~m}$. The total-age curves for trembling aspen were converted to breast-height age curves for site indices 15, 19 and $23 \mathrm{~m}$ by eliminating all data for estimated years required to reach breast height. Curves then were started at breast height $(0$ years at $\mathrm{BH}$ ) and site index was defined as height at 50 years breast-height age. Some minor proportional adjustments were made so that curves passed exactly through the 50-year height specified for each of the three levels of site index.

\section{Results}

Height-growth models

Almost all the height-growth models gave precise results; however we found that the Newnham (1988) constrained version of the Ek (1971) nonlinear regression model usually had slightly better precision than the other models. We used the Newnham model for all subsequent computations because this flexible nonlinear regression model accurately expresses polymorphic height-growth patterns and also constrains fitted curves to pass exactly through tree height specified at index age (Carmean et al. 1989).

\section{Restricting maximum age of computation data}

For both species separate equations were developed using data for 80 years, 100 years and no age restrictions; these three equations were used to generate height-growth curves from 0 to 150 years breast-height age for black spruce site index levels of 7, 12 and $17 \mathrm{~m}$, and for trembling aspen site index levels 15,19 and $23 \mathrm{~m}$.

Comparisons of these three age-restricted curves using the three levels of site index showed that the height-growth curves were similar. For both species differences in predicted heights using the three maximum age of date equations were less than $1.0 \mathrm{~m}$. Tukey's procedure (Steel and Torrie 1980) was used to test for significance between these small differences in predicted heights; for both species we found that height differences at 80 and 100 years were not significantly different.

We conclude that the three maximum age-restricted equations were similar and that for our black spruce and trem-

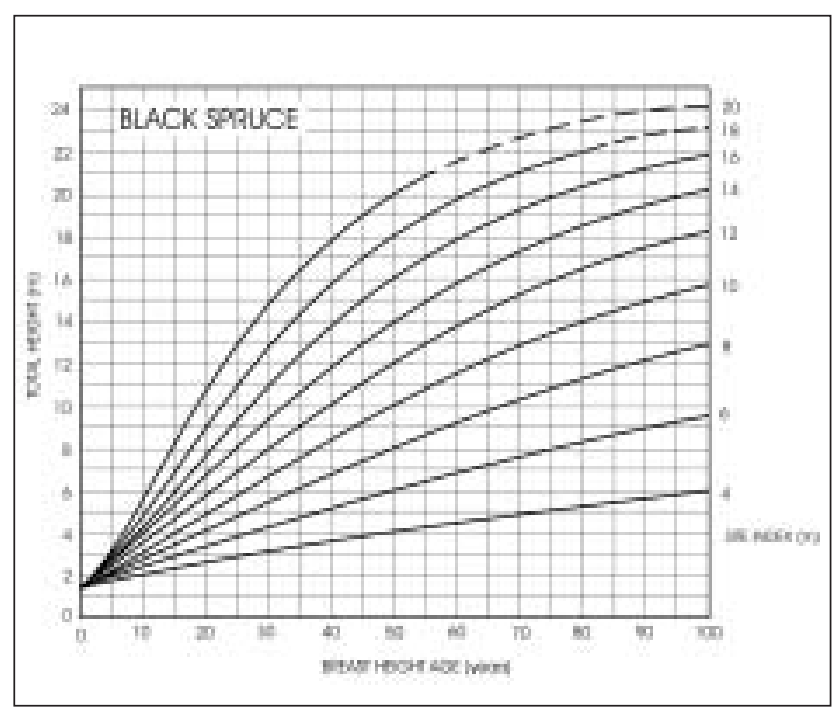

Fig. 1. Polymorphic site index curves for black spruce in Northwest Ontario. These curves are based on stem-analysis data from dominant and codominant trees in 230 plots in natural, fully-stocked, even-aged, undisturbed stands growing on mineral and organic soils. The Newnham (1988) constrained nonlinear regression model (eq. 1) was used for fitting these curves using data 100 years and less breast-height $(1.3 \mathrm{~m})$ age; dashed lines indicate extrapolations beyond stem-analysis data.

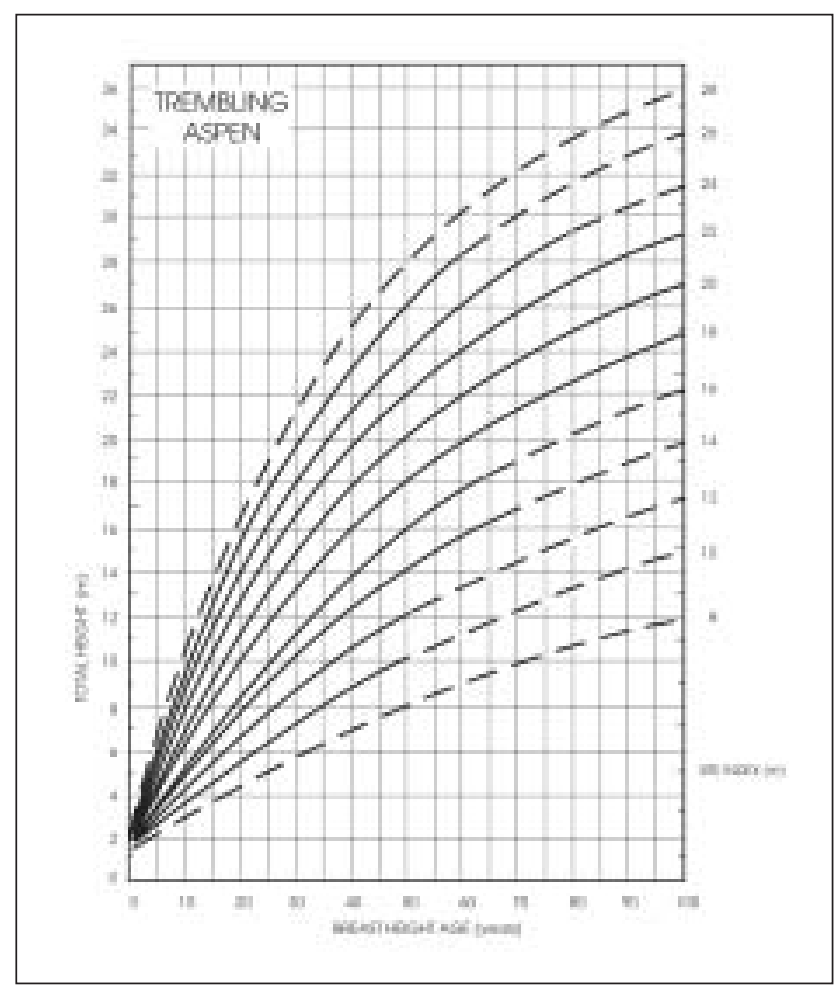

Fig. 2. Polymorphic site index curves for trembling aspen in Northwest Ontario. These curves are based on stem-analysis data from dominant and codominant trees in 194 plots in natural, fully-stocked, even-aged, undisturbed trembling aspen stands growing on mineral soils. The Newnham (1988) constrained nonlinear regression model (eq. 2) was used for fitting these curves using data 100 years and less breast-height $(1.3 \mathrm{~m})$ age; dashed lines indicate extrapolations beyond stem-analysis data. 
bling aspen curves the inclusion of data older than 100 years breast-height age would not distort our site index curves. Any of the three equations could be used for constructing black spruce and trembling aspen site index curves and they could be extended as far as 150 years breast-height age. We chose to use 100 years breast-height age as the maximum age limitation for data used in formulating our site index curves (Fig. 1 and 2). In northern Ontario black spruce and trembling aspen usually are managed at ages less than 100 years; therefore, extending site index curves beyond 100 years would have relatively little value for normal forest management.

For black spruce the Newnham (1988) equation using data 100 years and less breast-height age was:

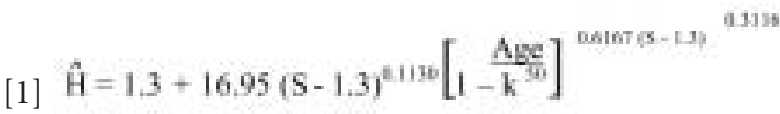

$$
\begin{aligned}
& \text { where } k=1-\left[\frac{(S-1.3)}{16.95(S-1.3)^{1112 \pi}}\right]^{\frac{1}{0.6167(S-1.3)^{0.016}}} \\
& \mathrm{R}^{2}=0.985 ; \mathrm{MSE}=0.425
\end{aligned}
$$

For trembling aspen the Newnham (1988) equation using data 100 years and less breast-height age is:

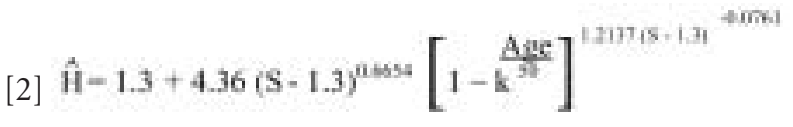$$
\text { where } k=1 \cdot\left[\frac{(\mathrm{S}-1.3)}{4.36(\mathrm{~S}-1.3)^{0.044}}\right]^{\frac{1}{1.2137(\mathrm{~S}-1.3)^{-4.0 \mathrm{mat}}}}
$$

$$
\mathrm{R}^{2}=0.985 ; \mathrm{MSE}=0.702
$$

Note: $\hat{H}=$ predicted height $(\mathrm{m})$ of dominant and codominant trees

$\mathrm{S}=\quad$ site index is average height $(\mathrm{m})$ of dominant and codominant trees at 50 years breast-height age

Age $=$ breast-height age (years)

\section{Polymorphic height-growth patterns}

Polymorphic height-growth patterns can be expressed by single Newnham equations (eq. 1 and 2) that are based on combining all data sets for both species. Polymorphism also can be expressed by separately fitting curves using data confined to good, medium and poor levels of site index. For both species we found similar polymorphic patterns of height growth using the three site-class equations when compared to polymorphic patterns expressed using a single Newnham equation. For both species at 80 and 100 years differences in predicted heights between single and site-class equations were less than $1.0 \mathrm{~m}$. Ordinary t-tests (Steel and Torrie 1980) were used to test for significance in these small differences in predicted heights; for both species we found that differences were not significantly different at ages 80 and 100 years.

We conclude that these close agreements are a confirmation of the suitability of single Newnham (1988) equations (eq. 1 and 2) for accurately expressing polymorphic height growth for both black spruce and trembling aspen 100 years and less breast-height age. For trees 150 years of age differences were somewhat larger for very good and for poor sites thus indicating that extending site index curves as far as 150 years would result in somewhat less precision in estimating site index.

\section{Data-set comparisons}

For black spruce separate equations for each of the five data sets were used for generating height-growth curves from 0 to 100 years breast-height age for SI 7, 12 and $17 \mathrm{~m}$. Heightgrowth curves also were generated using eq. 1 that combined data 100 years and less from the entire 230-plot data set. Likewise for trembling aspen, separate equations for each of the three data sets were used for generating height-growth curves from 0 to 100 years breast-height age for SI 15, 19 and $23 \mathrm{~m}$; height-growth curves also were generated using eq. 2 that combined data 100 years and less from the entire 194plot data set.

Results for black spruce showed that differences in estimated heights between the five data-set curves and the combined data-set curves were less than $1.0 \mathrm{~m}$ at 80 and 100 years. Likewise, results for trembling aspen showed that differences in estimated heights at 80 years were less than $1.0 \mathrm{~m}$ for SI 15 and SI $19 \mathrm{~m}$; however, differences exceeded $1.0 \mathrm{~m}$ for SI $23 \mathrm{~m}$. At 100 years differences in predicted heights for trembling aspen were less than $1.0 \mathrm{~m}$ for SI 15 but exceeded $1.0 \mathrm{~m}$ for SI 19 and SI $23 \mathrm{~m}$.

These differences in predicted heights at 80 and 100 years between the separate and independent black spruce and trembling aspen data-set curves were tested for significance using Dunnett's test (Steel and Torrie 1980). These tests indicated that the five black spruce data-set curves and the three trembling aspen data-set curves were not significantly different at 80 and 100 years breast-height age. These similarities for the five black spruce data-set curves at 80 and 100 years indicate that data for the five data-sets could be combined for computing a single equation (eq. 1) suitable for constructing a single set of black spruce site index curves for Northwest Ontario (Fig. 1). Likewise, the similarities for the three trembling aspen data-set curves at 80 and 100 years breast-height age indicate that data for the three data sets could be combined for computing a single equation (eq. 2) suitable for constructing a single set of trembling aspen site index curves for Northwest Ontario (Fig. 2).

Differences in predicted height at 150 years breast-height age for both black spruce and trembling aspen usually were greater than $1.0 \mathrm{~m}$ indicating less precision in predicting site index for older stands. Therefore, our results indicate that projecting our site index curves beyond 100 years breastheight age would result in somewhat less precise predictions of site index.

\section{Discussion}

\section{Comparisons with other site index curves}

Pronounced differences were evident for older ages when our black spruce and trembling aspen site index curves were compared to published black spruce and trembling aspen site index curves for other areas (Fig. 3 and 4). Our curves have more pronounced polymorphic patterns than all other 

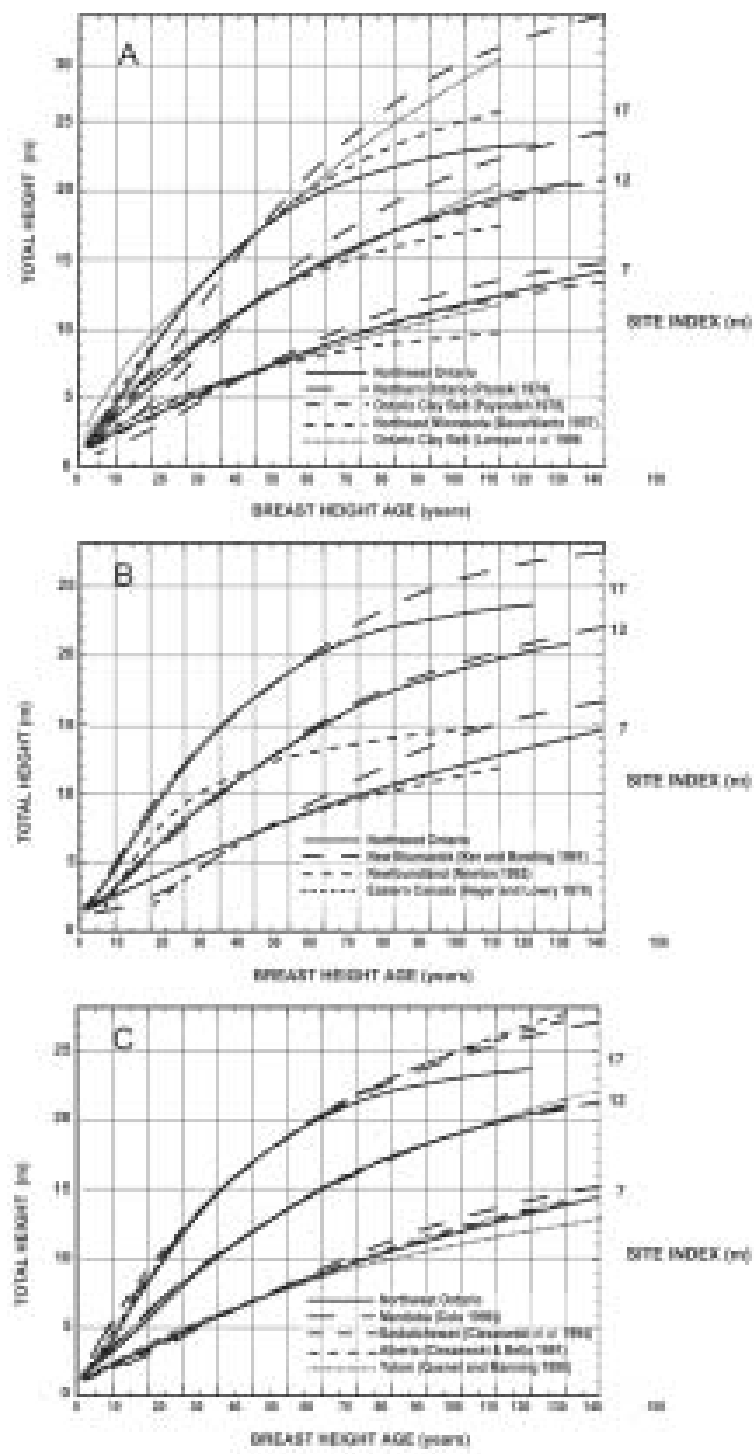

Fig. 3. Comparisons between our polymorphic black spruce site index curves for Northwest Ontario (eq. 1) and other black spruce site index curves for Minnesota and for Canada.

curves. The reason may be that our curves are based on actual stem-analysis data from very wide ranges of site index and age; therefore, our curves are not extrapolations beyond observed ages and levels of site index.

Reasons for the differences between our curves and other curves are unknown but it is not likely that these illustrated differences are due only to growth effects related to regional differences in climate, soil and topography. Many of the differences illustrated in Fig. 3 and 4 could be artifacts related to the kind and amount of data as well as the methods of statistical analysis and to how well the data sets actually represent the full range of site index and tree age of the various regions. Many of the differences illustrated in Fig. 3 and 4 for other curves might be related to extrapolations far beyond actual measured data for these curves.

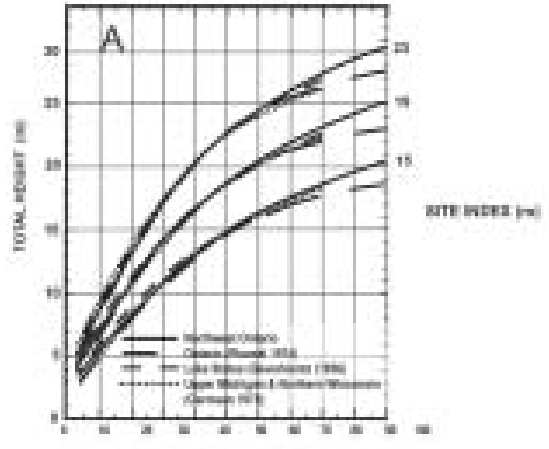

nevir neast Nme irew
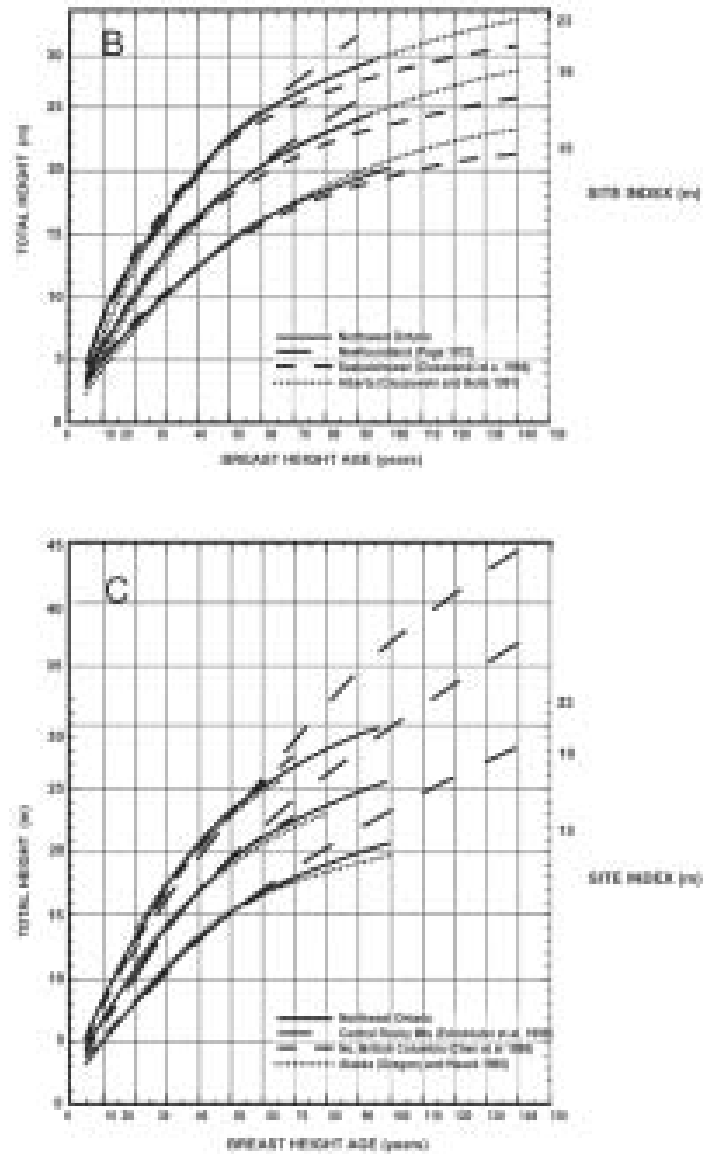

Fig. 4. Comparisons between our polymorphic trembling aspen site index curves for Northwest Ontario (eq. 2) and other trembling aspen site index curves for Canada and the United States.

Some of the earlier black spruce and trembling aspen curves (Table 1) were anamorphic and thus not capable of expressing polymorphic tree-height growth. Also, many earlier anamorphic curves were based only on paired total-height and total-age measurements rather than on stem-analysis data. Frequently, only limited data were available, or data were not reported; thus, we often are uncertain about the actual 
range of site index and tree age measured in these other studies. Therefore, we suspect that some of the older published site index curves may have been extrapolated far beyond the levels of site index and tree ages that were actually measured. We found that polymorphism is most evident for older ages when comparisons are made for very good and very poor levels of site index (Fig. 3 and 4). We can hardly expect to find much polymorphism expressed by site index curves based mostly on data from young stands located mostly on soils having medium levels of site index.

For example, Gevorkiantz's (1957) curves for black spruce (Fig. 3A) are based only on paired total-height and total-age values and on harmonizing methods that produce proportional anamorphic curves that cannot express polymorphic height-growth patterns. Furthermore, these anamorphic curves are based on total-age instead of breast-height age; therefore, slow and erratic height growth below breast height probably introduced serious errors in estimating early treeheight growth. In addition, we are uncertain about the number of plots or about the actual ages and site indices for black spruce represented by the Gevorkiantz data set. Thus, curves for older ages, and for very good and very poor sites, might be extrapolations far beyond actual observations. Our study for Northwest Ontario shows that few older black spruce stands occur on good sites (Table 3). This same lack of older black spruce stands on good sites may have been encountered by Gevorkiantz where his curves for older ages on good sites $(\mathrm{SI}<17 \mathrm{~m})$ may be extrapolations not supported by actual measurements.

Plonski's (1974) anamorphic site-class curves for black spruce on good sites show an unusual pattern of rapid height growth after 50 years (Fig. 3A). However, the Plonski curves were developed using graphical methods not capable of expressing the polymorphic height-growth patterns that we have found to be most pronounced for older-aged black spruce stands. Moreover, the Plonski curves are based on total-age and do not include height-growth predictions for ages younger than 20 years; our studies show that slow and erratic height growth below breast height can be a major source of error. Finally, no evidence is provided about the range of site index or tree age represented in the Plonski data set. Accordingly, we are uncertain about possible extrapolations that might greatly exceed the actual levels of observed site index and age used in the Plonski site-class curves.

Unusual rapid height-growth predictions for black spruce after 50 years for good sites can also be observed for the Larocque et al. (1996) curves (Fig. 3A). Possibly these unusual patterns are related to basing the curves on total-age and to a lack of data representing older ages on good sites.

Some of the differences in height-growth patterns illustrated in Fig. 3 and 4 may actually be real differences related to soil, climate or topographic differences. The Newton (1992) black spruce curves (Fig. 3B) for Newfoundland had only a single plot older than 100 years; also, plots older than 80 years were not available to represent height growth on good sites. Therefore, the unusually slow growth at older ages predicted by the Newton curves may be caused by extrapolations beyond actual observations. However, Page and van Nostrand (1971) illustrated the lack of data for good sites, as well as the unusually slow later height growth for older black spruce in Newfoundland. They thought that curve shapes for black spruce in Newfoundland differed from curve shapes for black spruce in continental Canada and attributed slower later height growth to the shallow rooting of black spruce as well as to high velocity winds in maritime Newfoundland that might limit dominant tree-height growth.

The slow concave-shaped early height growth for black spruce on poor sites in both Newfoundland (Newton 1992) and New Brunswick (Ker and Bowling 1991) (Fig. 3B) may be due to effects of understory Kalmia and Vaccinium. These ericacious plants have allelopathic compounds that inhibit early height growth of planted black spruce on poor sites in central Newfoundland (Mallik 1999); these same understory plants also inhibit early height growth of jack pine (Pinus banksiana Lamb.) on poor and medium sites in New Brunswick (Hamilton and Krause 1985).

The Newfoundland curves (Page 1972) for trembling aspen (Fig. 4B) show exceptionally good growth after 50 years for good sites. These are harmonized curves based only on paired total-height and breast-height-age values; analytical methods used for developing these curves are not described but apparently these methods were unable to express polymorphic height growth. Also, these curves may have lacked plots representing height growth for older-aged trembling aspen.

The site index curves for trembling aspen in the Rocky Mountains (Edminster et al. 1985) show exceptionally rapid height growth for older ages (Fig. 4C). We are uncertain if these are extrapolations beyond observed plot data; however, trembling aspen in the Rocky Mountains area grows to ages older than in other regions possibly due to less incidence of hypoxylon canker (Perala 1977). The site index curves for trembling aspen in Alaska (Gregory and Haack 1965) show much slower height growth after 50 years than do other curves (Fig. 4C); this slower later growth might be partially related to climatic differences. Also to be considered is that these total-age harmonized curves are not capable of expressing polymorphic height growth and, in addition, these curves may be based on limited data for trees older than 80 years or for sites better than site index $18 \mathrm{~m}$.

A conclusion based on these site index curve comparisons is that using trees and stands older than 100 years may result in less precise site index estimations. Reasons are: (a) trees older than 100 years require many years projection back to estimated tree height at the 50-year index age (site index), but trees ranging perhaps from 30 to 70 years of age require much less projection forward or backward to index age 50 years and; (b) many site index curves extending beyond 100 years may be based on limited data or may be extrapolations far beyond actual observations of age and site quality and so may be less precise for estimating site index.

\section{Site quality distribution}

Black spruce and windthrow

A strong and consistent trend occurs for older black spruce plots to be on mostly poor sites for both mineral and organic soils in the North Central and Northwestern Regions of Northwest Ontario (Table 3). We had 49 plots on good sites (SI $15 \mathrm{~m}$ and better) but only four of these plots were older than 100 years breast-height age. Most of our plots older than 
100 years were on poor sites; our five oldest plots were 150-170 years breast-height age but these had site indices less than $9.0 \mathrm{~m}$.

This same lack of older black spruce stands on good sites also has been reported for the Clay Belt of Northeast Ontario (Woods and Beckwith 1987). Additional Clay Belt studies by Smith et al. (1987) using tree winching showed that shallowrooted black spruce are susceptible to windthrow once they reach a critical height of 20 to $21 \mathrm{~m}$. Our results indicate that black spruce on good site quality mineral and organic soils in Northwest Ontario may also suffer from windthrow similar to that reported for black spruce on good site quality Clay Belt soils in Northeast Ontario.

Lack of older black spruce stands on good sites has management implication: (a) rotation lengths-Black spruce are shallow-rooted and tall trees apparently are prone to windthrow because more leverage is associated with tall trees. If we accept the critical windthrow height of $20 \mathrm{~m}$ (Smith et al. 1987), then the black spruce site index curves (Fig. 1) can be used to estimate the breast-height age when dominant and codominant black spruce reach a total height of $20 \mathrm{~m}$ where windthrow becomes a hazard. Fig. 1 shows that $20 \mathrm{~m}$ height is reached at 50, 62, 76 and 96 years breast-height age for site indices 20,18, 16 and $14 \mathrm{~m}$, respectively. Accordingly, this indicates that rotation lengths for black spruce should be shorter as site index becomes better; (b) thinning - Thinning older black spruce stands on good sites probably should be avoided because reduced stocking would increase windthrow hazard; and (c) species selection-Long rotations on good sites have the potential for producing valued sawlogs and veneer logs as well as valued utility poles and cabin logs. However, for black spruce such products require long rotations where windthrow hazard becomes greater. Accordingly, for good sites managers could consider stand conversion to long-lived more windfirm species such as red pine (Pinus resinosa Ait.) or white pine (P. strobus L.).

\section{Trembling aspen and stand breakup}

A strong and consistent trend occurs for trembling aspen plots to be mostly on good sites (Table 3 ). We only had two poor site $(\mathrm{SI}<12.0 \mathrm{~m})$ and five medium-poor site (SI 12.0 to $13.9 \mathrm{~m}$ ) plots despite efforts to locate measurable aspen plots on poor sites. Our observations are that aspen may become established on poor sites after harvesting but early stand breakup usually occurs and few stands survive by 50 years breast-height age.

Early stand breakup for trembling aspen has been reported for the Great Lakes area (Fralish 1972, Shields and Bockheim 1981). The reason for this breakup is increased mortality from white trunk rot and hypoxylon canker (Perala 1977). Recent studies also show a relationship between insect wounds, woodpecker feeding and increased infection by hypoxylon spores (Ostry and Anderson 1998). Accordingly, our lack of older aspen plots on poor sites apparently is related to early stand breakup.

The lack of merchantable trembling aspen stands on poor sites has management implications for trembling aspen. Field foresters have long recognized poor growth and survival for "off-site" trembling aspen stands. Our soil-site studies (Carmean and Li 1998) have defined these "off-sites" as shallow to bedrock soils, gravelly morainal soils, coarse-textured sands, poorly-drained soils and organic soils. These soil-site studies and our site index curve studies indicate that such "off-site" soils are not suitable for aspen management; therefore, silvicultural efforts should be taken to retain conifer stands on these sites.

\section{Conclusions}

We consider that eq. 1 and Fig. 1 for black spruce are applicable to both upland mineral soils and organic soils throughout Northwest Ontario. This conclusion was reached because our black spruce data-set curves for mineral and organic soils were similar for both the North Central and Northwestern Regions. Likewise we consider that eq. 2 and Fig. 2 for trembling aspen is applicable to mineral soils throughout Northwest Ontario. This conclusion was reached because our separate data-set curves for trembling aspen curves on mineral soils were similar for both the North Central and Northwestern Regions of Northwest Ontario.

\section{Acknowledgements}

Portions of this research were funded by the Canadian Forestry Service Human Resources Development Fund, the National Sciences and Engineering Research Council and a research grant from the Lakehead University Centre for Northern Studies. Special appreciation is extended to the Ontario Ministry of Natural Resources Northwest Science and Information Unit that provided FEC (Forest Ecosystem Classification) plot data; they also provided locations of mature black spruce and trembling aspen stands, assisted with the field collection of stem-analysis data and assisted with the TRIM (Tree Ring Increment Measuring) system processing of data. Much of the collection and processing of black spruce stem-analysis data was done by Kristof SasZmudinski.

\section{References}

Adams, R.D. (ed.). 1990. Aspen symposium '89 proceedings. USDA For. Serv. North Cent. For. Expt. Stn. Gen. Tech. Rpt. NC-GTR-140, St. Paul, MN. 348 p.

Burkhart, H.E. and R.B. Tennent. 1977. Site index equations for radiata pine in New Zealand. New Zeal. J. For. Sci. 7: 408-416.

Carmean, W.H. 1972. Site index curves for upland oaks in the Central States. Forest Sci. 18: 109-120.

Carmean, W.H. 1975. Forest site quality evaluation in the United States. Adv. in Agron. 27: 209-269.

Carmean, W.H. 1978. Site index curves for northern hardwoods in northern Wisconsin and Upper Michigan. USDA For. Serv. North Cent. For. Expt. Stn. Res. Pap. NC-160, St. Paul, MN. 16 p.

Carmean, W.H. 1996. Site-quality evaluation, site-quality maintenance, and site-specific management for forest land in Northwest Ontario. Ont. Min. Nat. Resour. Northwest Sci. and Tech. Tech. Rpt. NWST-105. Thunder Bay, ON. 121 p.

Carmean, W.H., J.T. Hahn and R.D. Jacobs. 1989. Site index curves for forest species in the eastern United States. USDA For. Serv. North Cent. For. Expt. Stn. Gen. Tech. Rpt. NC-GTR-128. St. Paul, MN. 142 p. Carmean, W.H. and D.J. Lenthall. 1989. Height-growth and site index curves for jack pine in North Central Ontario. Can. J. For. Res. 19: 215-224.

Carmean, W.H. and Y. Li. 1998. Soil-site relations for trembling aspen in Northwest Ontario. North. J. Appl. For. 15(3): 146-153.

Carmean, W.H., G.P. Niznowski and G. Hazenberg. 2001. Polymorphic site index curves for jack pine in northern Ontario. For. Chron. 77(1): 141-150. 
Chen, H.Y., H.K. Klinka and R.D. Kabzems. 1998. Height-growth and site index models for trembling aspen (Populus tremuloides Michx.) in northern British Columbia. For. Ecol. Manage. 102: 157-165.

Cieszewski, C.J. and I.E. Bella. 1991. Polymorphic height and site index curves for the major tree species in Alberta. For. Canada, Northwest Reg., For. Mgt. Note 51, Edmonton, AB. 7 p.

Cieszewski, C.J., I.E. Bella and D.P. Yeung. 1994. Preliminary site index height-growth curves for eleven timber species in Saskatchewan. Can. For. Serv. Northwest Reg., Edmonton, AB. 22 p. (unpublished ms.).

Cole, J.C. 1996. Polymorphic site index curves for black spruce (Picea mariana [Mill.] B.S.P.) in the Nelson River Forest District of northern Manitoba. B.Sc. For. thesis, Lakehead Univ. Fac. Forestry, Thunder Bay, ON. 47 p.

David, A.J., J.C. Zasada, D.W. Gilmore and S.M. Landhausser. 2001. Current trends in the management of aspen and mixed aspen forests for sustainable production. For. Chron. 77(3): 525-531.

Davidson, R.W., R.C. Atkins, R.D. Fry, G.D. Racey and D.H. Weingartner. 1988. A silvicultural guide for the poplar working group in Ontario. Ont. Min. Nat. Resour. Sci. and Tech. Ser., Vol. 5. Toronto, ON. 67 p.

Dempster, W.R. and Associates Ltd. 1983. Yield tables for Alberta forest cover types. Can. For. Serv. Northwest Reg., Edmonton, AB. 227 p. (unpublished report).

Deschamps, K.C. 1991. Height-growth and site index curves of trembling aspen in North Central Ontario. M.Sc.F. thesis, Lakehead Univ. Fac. For., Thunder Bay, ON. 109 p.

Dyer, M.E. and R.L. Bailey. 1987. A test of six methods for estimating true heights from stem-analysis data. For. Sci. 33: 3-13.

Edminster, C.B., H.T. Mower and W.D. Shepperd. 1985. Site index curves for aspen in the Central Rocky Mountains. USDA For. Serv., Rocky Mt. For. and Range Expt. Stn. Res. Note RM-453. Fort Collins, CO. 4 p.

Ek, A.R. 1971. A formula for white spruce site index curves. Univ. Wis. For. Res. Note No. 161. 1 p.

Fralish, J.S. 1972. Youth, maturity, and old age. In Proc. Aspen Symp. pp. 42-58. USDA For. Serv. North Cent. For. Expt. Stn. Gen. Tech. Rpt. NC-GTR-1. St. Paul, MN. 54 p.

Gevorkiantz, S.R. 1956. Site index curves for aspen in the Lake States. USDA For. Serv., Lake States For. Expt. Stn. Tech. Note 464. St. Paul, MN. 2 p.

Gevorkiantz, S.R. 1957. Site index curves for black spruce in the Lake States. USDA For. Serv., Lake States For. Expt. Stn. Tech. Note 473. St. Paul, MN. 2 p.

Gregory, R.A. and P.M. Haack. 1965. Growth and yield of wellstocked aspen and birch stands in Alaska. USDA For. Serv. Pac. Northwest For. Expt. Stn. Res. Pap. NOR-2. Portland, OR. 15 p.

Hamilton, W.N. and H.H. Krause. 1985. Relationships between jack pine growth and site variables in New Brunswick plantations. Can. J. For. Res. 15: 922-926.

Hearnden, K.W., S.V. Millson and W.C. Wilson. 1992. A report on the status of forest regeneration. Ontario Min. Nat. Resour., For. Audit Sec., Sault Ste. Marie, ON. 117 p.

Heger, L. and G.L. Lowry. 1971. Forest site studies IV. Site index curve shape in black spruce in eastern Canada. Pulp and Paper Inst. Canada. Woodlands Rpt. WR/27. Pointe Claire, PQ. 12 p.

Ker, M.F. and C. Bowling. 1991. Polymorphic site index equations for four New Brunswick softwood species. Can. J. For. Res. 21: 728-732.

Larocque, G.R., W.J. Parton and D.J. Archibald. 1996. Polymorphic site productivity functions for black spruce in relation to different ecological types in northern Ontario. Ont. Min. Nat. Resour. Northeast Sci. and Tech. NEST Tech. Rep. TR-033. South Porcupine, ON. 19 p.
Li, Y. 1991. Soil-site relations for trembling aspen (Populus tremuloides Michx.) in Northwestern Ontario. M.Sc.F. thesis, Lakehead Univ. Sch. For., Thunder Bay, ON. 127 p.

Lundgren, A.L. and W.A. Dolid. 1970. Biological growth functions describe published site index curves for Lake States timber species. USDA For. Serv. North Cent. For. Expt. Stn. Res. Pap. NC-36. St. Paul, MN. 9 p.

Mallik, A.V. 1999. Growth response of planted black spruce (Picea mariana) to sites with and without high cover of Kalmia angustifolia. (Abst. p. 129). Second World Congress on Allelopathy. Lakehead Univ., Thunder Bay, ON.

MacIver, D.C., F. Raymond and H. Sallans. 1985. TRIM sampling design manual. Ontario Min. Nat. Resour. Forest Resour., Toronto, ON. 178 p.

Monserud, R.A. 1984. Height-growth and site index curves for inland Douglas-fir based on stem-analysis data and forest habitat type. For. Sci. 30: 943-965.

Morley, P.M. and J.J. Balatinecz. 1993. Poplar utilization in Canada: past, present and future. For. Chron. 69(1): 46-52.

Navratil, S. and P.B. Chapman. (eds.). 1991. Aspen management for the 21st century. For. Canada, Northwest Reg. and Poplar Council of Canada, Edmonton, AB. 172 p.

Navratil, S., L.G. Brace, E.A. Sauder and S. Lux. 1994. Silvicultural and harvesting options to favor immature white spruce and aspen regeneration in boreal mixedwoods. Can. For. Serv. Rpt. NOR-X337. Edmonton, AB. 78 p.

Newnham, R.M. 1988. A modification of the Ek-Payandeh nonlinear regression model for site index curves. Can. J. For. Res. 18: $115-120$.

Newton, P.F. 1992. Base-age invariant polymorphic site index curves for black spruce and balsam fir within Central Newfoundland. North. J. Appl. For. 9(1): 18-22.

Nigh, G.D., P.V. Knestor and K. Klinka. 2002. Height-growth of black spruce in British Columbia. For. Chron 78(2):306-313.

Ontario Ministry of Natural Resources. 2002. Forest resources of Ontario - 2001. Ontario Min. Nat. Resour., Peterborough, ON. 137 p. Ostry, M.E. and N.A. Anderson. 1998. Interactions of insects, woodpeckers and hypoxylon canker on aspen. USDA For. Serv. North Cent. For. Expt. Stn. Res. Pap. NC-331. St. Paul, MN. 15 p.

Page, G. 1972. The occurrence and growth of trembling aspen in Newfoundland. Can. For. Serv. Publ. 1314. Ottawa, ON. 15 p.

Page, G. and R.S. van Nostrand. 1971. Growth of black spruce in eastern Canada. For. Chron. 47(6): 355.

Payandeh, B. 1974. Formulated site index curves for major timber species in Ontario. For. Sci. 20:143-144.

Payandeh, B. 1978. A site index formula for peatland black spruce in Ontario. For. Chron. 54:39-41.

Perala, D.A. 1977. Manager's handbook for aspen in the North Central States. USDA For. Serv. North Cent. For. Expt. Stn. Gen. Tech. Rpt. NC-36. St. Paul, MN. 30 p.

Perala, D.A. 1990. Quaking aspen. In R.M. Burns and B.H. Honkala (Tech. Coords.). Silvics of North America: Vol. 2. Hardwoods. pp. 555-569. USDA Agric. Handb. 654. Washington, DC. 877 p.

Perala, D.A. 1991. Renewing decadent aspen stands. In S. Navratil and P.B. Chapman (eds.). Aspen management for the $21^{\text {st }}$ century. pp. 77-82. For. Canada, Northwest Reg. and Poplar Council of Canada. Edmonton, AB. 172 p.

Peterson, E.B. and N.M. Peterson. 1992. Ecology, management, and use of aspen and balsam poplar in the prairie provinces. For. Canada, North. For. Ctr. Spec. Rpt. 1. Edmonton, AB. 252 p.

Peterson, E.B. and N.M. Peterson. 1995. Aspen managers' handbook for British Columbia. Can. For. Serv., Pacific For. Ctr. FRDA Rept. 230. Victoria, BC. 110 p.

Plonski, W.L. 1974. Normal yield tables (metric) for major forest species of Ontario. Ontario Min. Nat. Resour., Toronto, ON. 33 p. 
Pollock, J.W. 1994. Polymorphic site index curves for black spruce (Picea mariana [Mill.] B.S.P.) in north central Manitoba. Univ. New Brunswick, B.Sc.For. thesis, Fredericton, NB. 34 p.

Quenet, R.V. and G.H. Manning. 1990. Site index equations for black spruce and white spruce in the Yukon. For. Canada, Pacific For. Ctr. Inf. Rpt. BC-X-317. Victoria, BC. 19 p.

Shepperd, W.D., D. Binkley, D.L. Bartos, T.J. Stohlgren and L.G. Eskew (comps.). 2001. Sustaining aspen in western landscapes: Sym. Proc. USDA For. Serv. Rocky Mt. Res. Stn. RMRS-P-18. Fort Collins, CO. 460 p.

Shields, W.J., Jr. and J.G. Bockheim. 1981. Deterioration of trembling aspen clones in the Great Lakes region. Can. J. For. Res. 11: 530-537.

Sims, R.A., W.D. Towill, K.A. Baldwin and G.M. Wickware. 1989. Field guide to the forest ecosystem classification for Northwestern Ontario. Ont. Min. Nat. Resour. Northwest. Ont. For. Tech. Dev. Unit, Thunder Bay, ON. 191 p.
Smith, V.G., M. Watts and D.F. James. 1987. Mechanical stability of black spruce in the Clay Belt Region of northern Ontario. Can. J. For. Res. 17: 1080-1091.

Steel, R.G.D. and J.H. Torrie. 1980. Principles and procedures of statistics - a biometrical approach. McGraw-Hill Book Co., Toronto, ON. 633 p.

Viereck, L.A. and W.F. Johnson. 1990. Black spruce. In R.M. Burns and B.H. Honkala (Tech. Coords.). Silvics of North America: Vol. 1. Conifers. pp. 227-237. USDA Agric. Handb. 654. Washington, DC. $675 \mathrm{p}$.

Woods, M.E. and A.F. Beckwith. 1987. Storability of black spruce in the Clay Belt. Ontario Min. Nat. Resour., Timber Sales Br., MGS Publ. Serv. Sec., Toronto, ON. 15 p. 